\title{
INFLUENCE OF MALE OBESITY ON FERTILITY
}

\author{
Miro Kasum ${ }^{1}$, Sonja Anić-Jurica ${ }^{1}$, Ermin Čehić², Tajana Klepac-Pulanić3 \\ Josip Juras ${ }^{1}$ and Kristina Žužul ${ }^{1}$
}

${ }^{1}$ Clinical Department of Obstetrics and Gynecology, Zagreb University Hospital Center, School of Medicine, University of Zagreb, Zagreb, Croatia; ${ }^{2}$ Zenica Cantonal Hospital, Zenica, Bosnia and Herzegovina; ${ }^{3}$ Zagreb-East Health Center, Department of Gynecology, Zagreb, Croatia

\begin{abstract}
SUMMARY - The aim of this review is to analyze current diagnostic approaches to obesity in adult men, the potential mechanisms linking obesity to infertility, and treatment options aimed at improving reproductive health. Obesity has become a worldwide epidemic with the estimated prevalence increasing from $28.8 \%$ to $36.9 \%$ between 1980 and 2013. In terms of diagnosis, numerous simple techniques have been developed including body mass index, waist to hip ratio, waist circumference, bioelectrical impedance analysis, ultrasound and skinfold measurements. Additionally, several other less available but more accurate techniques have been suggested, such as air displacement plethysmography, dual energy $\mathrm{x}$-ray absorptiometry, computed tomography and magnetic resonance imaging. In addition to cardiovascular and other disorders, male obesity can negatively affect the male reproductive potential through abnormal reproductive hormone levels, reduced semen quality, increased release of adipose-derived hormones and adipokines, as well as thermal, genetic and sexual mechanisms. In the management of obesity related male infertility, natural weight loss is the cornerstone and regular exercise the first-line treatment. Although bariatric surgery results in greater improvements in weight loss outcomes when compared to non-surgical interventions, further research is required to clarify its overall influence on male fertility.
\end{abstract}

Key words: Male; Obesity - diagnosis; Obesity - complications; Infertility, male - therapy

\section{Introduction}

Over the past three decades, many countries in the urbanized world have witnessed a growing epidemic of overweight and obesity. The epidemic is largely fueled by urbanization, economic growth, industrialization, mechanized transport, and the adoption of sedentary lifestyle, coupled with the high availability of foods with high caloric content ${ }^{1}$. Since the 1970s, the rates of excess body weight in reproductive-age men have nearly tripled, so that in westernized countries between $65 \%$ and $70 \%$ of adult men are currently overweight or obese. The estimated prevalence of over-

Correspondence to: Prof. Miro Kasum, $M D, P h D$, Clinical Department of Obstetrics and Gynecology, Zagreb University Hospital Center, Petrova 13, HR-10000 Zagreb, Croatia

E-mail: mkasum@gmail.com

Received August 17, 2015, accepted November 12, 2015 weight and obesity in adults worldwide has increased between 1980 and 2013 from $28.8 \%$ to $36.9 \%$ in men and from $29.8 \%$ to $38.0 \%$ in women, reaching epidemic proportions with 2.1 billion adults affected ${ }^{2}$. The obesity epidemic has received considerable attention as a major global health challenge because it is associated with an increased risk of a wide array of health problems, including diabetes, heart disease, hypertension, cancers, as well as many digestive diseases, exerting a heavy toll on the economy with its massive healthcare costs ${ }^{3}$.

Reproductive consequences of excess body weight in women have received substantial attention because obese women are more likely to experience ovulatory or menstrual disorders and delayed fertility. The ongoing pregnancy rate/cycle among obese women was found to be lower than in normal weight women $(20.8 \% \text { versus } 28.3 \%)^{4}$. Moreover, obesity has been as- 
sociated with an increased rate of polycystic ovary syndrome, infertility and treatment failure, multiple complications of pregnancy including miscarriages, gestational diabetes, preeclampsia, fetal macrosomia and cesarean delivery with poor neonatal and maternal pregnancy outcomes ${ }^{5}$.

Until recently, the reproductive consequences of obesity on the male reproductive potential have been studied to a lesser extent, although it has equally been linked to male infertility. The studies reporting correlations between obesity and fertility have generally been inconclusive because it remains unclear to what extent obesity affects the reproductive potential in men. In several studies, it has been suggested that overweight and obese men showed no significantly increased relative risk of abnormal semen parameters ${ }^{6-8}$. A systematic review with meta-analysis of 31 studies on 6800 men revealed little association between increased body mass index (BMI), average sperm concentration and total sperm count. There was, however, strong evidence for a negative relationship between increased BMI and the levels of testosterone, sex hormone binding globulin (SHBG) and free testosterone $e^{6}$. These results support the earlier findings in a study on 2139 cases where overweight and obese men had a markedly changed sex hormone profile in serum, whereas reduction of semen quality was marginal ${ }^{7}$. Similarly, no significant correlation was found between BMI and semen parameters measured in a recently published cross-sectional study on $511 \mathrm{men}^{8}$. However, since recently, it is being increasingly documented that male excess body weight has a negative impact on semen parameters ${ }^{9-11}$. A recent meta-analysis including 21 studies and a sample of 13077 men concluded that overweight and obesity were associated with an increased prevalence of azoospermia or oligozoospermia and a significantly elevated risk of abnormal sperm count, when compared with normal weight subjects ${ }^{9}$. It seems that obesity leads to a higher risk of sperm DNA damage in infertile patients because the DNA fragmentation rate was found to be significantly higher in obese, but not in overweight $\operatorname{men}^{10}$. When examining semen parameters, ejaculate volume, sperm concentration and total sperm count were found to show linear decline with increasing BMI and waist circumference (WC) ${ }^{11}$. Moreover, erectile dysfunction and low testosterone are frequently accompanied by obesity, particularly central obesity, which can also be a cause of infertility or reproductive difficulties ${ }^{12}$. Furthermore, male obesity may be associated with various comorbidities, including metabolic syndrome, hypercholesterolemia, hyperleptinemia, psychological depression, sleep apnea, renal failure, type 2 diabetes mellitus and cardiovascular diseases, all of which have independently been linked to male subfertility. Therefore, it seems that the effects of male obesity and comorbidities on fertility are multifactorial, influencing sperm parameters, pregnancy and subsequent child health. Because it is unclear to what extent obesity affects the reproductive potential in men, it remains to be determined whether the exact effects occur through its higher level per se, an associated comorbidity, or a combination of both ${ }^{13}$. The purpose of the present review is to analyze the current diagnostic methods used to define obesity in adult males, the underlying mechanisms contributing to male infertility, as well as the treatment options which may lead to improvements in reproductive health.

\section{Diagnosis of Overweight and Obesity}

Currently, the terms 'overweight' and 'obesity' refer to abnormal or excessive fat accumulation that is greater than what is generally considered healthy for a given height. The terms also identify ranges of weight that have been shown to increase the likelihood of certain diseases, as well as other health problems ${ }^{14}$.

Numerous simple and accessible anthropometric techniques have been developed to evaluate the body fat content such as BMI, waist to hip ratio (WHR), WC, bioelectrical impedance analysis (BIA), ultrasound and skinfold measurements ${ }^{15-23}$. Traditionally, BMI has been the most widely used method in classifying overweight and obesity in adult populations because it provides a relatively good estimate of the risks associated with developing diseases that occur more frequently in people with higher body fat content. Although BMI provides a significantly better representation of the body fat content when compared to simply measuring body weight, it is only moderately correlated with the body fat mass. BMI is calculated as body weight adjusted for height (weight $\mathrm{kg}_{\mathrm{g}}$ height $\left._{\mathrm{m}}{ }^{2}\right)$ and it is the most commonly used diagnostic tool for generalized obesity. Despite its frequent use, BMI cannot be used to differentiate between subcutaneous and visceral fat compartments. A BMI greater than $25 \mathrm{~kg} / \mathrm{m}^{2}$ 
is used to define overweight, while a BMI over $30 \mathrm{~kg} / \mathrm{m}^{2}$ is characterized as obesity. Although BMI can be used in most individuals, it may overestimate adiposity in men whose higher body weight can be attributed to greater muscle and bone mass. However, BMI may also underestimate body fat in older people and others who have lost muscle mass. Therefore, when BMI is used to indicate adiposity, gender- and age-specific thresholds should also be taken into account ${ }^{15,16}$. In addition to BMI, alternative measurements such as WC, WHR and to a lesser extent the waist to height ratio can be used to more accurately describe the distribution of body fat. These methods have been suggested as superior to BMI in predicting health problems associated with central or visceral adiposity because abdominal or white fat tissue, rather than the total amount of fat, has been linked to obesity-related disorders ${ }^{17-19}$. WC is usually measured at the narrowest point between the lower border of the rib cage and the iliac crest. Men and women with WC values $\leq 102$ and $\leq 88$ $\mathrm{cm}$, respectively, are considered to have a normal WC, whereas men and women with WC values $>102$ and $>88 \mathrm{~cm}$, respectively, are considered to have a high $\mathrm{WC}^{17}$. WHR can also be used to predict serious health consequences as a result of increased body fat (normal WHR: males $\leq 0.9$ and females $<0.85)^{18}$. Although general and abdominal obesity measurements were found to be reliable predictors of obesity-related mortality, evidence from a recent meta-analysis suggests that WC or WHR provides additional information that is independent to BMI and should therefore be used in clinical practice ${ }^{19}$. During the last decade, the conventional BIA, a safe and cost-efficient method, has been widely used to estimate body composition and in particular the body fat content in clinical setting. However, BIA lacks the specificity and accuracy since it is based on measuring differences in resistance as the electrical current passes through fatty and lean components of the body. The resistance between the conductors will provide a measurement of body fat since resistance to the conduction of electricity varies between adipose, muscular and skeletal tissue. Fat-free mass (muscle) is a good conductor as it contains a large amount of water and electrolytes, while fat being anhydrous behaves as a poor conductor ${ }^{20}$. Recently, a newer and more accurate methodological variant, the bioelectrical impedance vector analysis (BIVA), has been used to successfully identify the relative propor- tion of fat mass in a large sample of adults ${ }^{21}$. Despite a nearly 50-year tradition of ultrasound usage to assess body fat in addition to many other body composition techniques, this method has not been adopted. Ultrasound can provide a site-specific evaluation of the skin, adipose tissue and muscle thicknesses, and it is being increasingly used to discriminate between visceral and subcutaneous adipose tissue. A comparison of the body fat measurements using a portable ultrasound to those measured by the calipers of the skinfold technique demonstrated no significant differences. Moreover, the ultrasound procedure was shown to be faster and more cost effective than the other laboratory methods. The biggest limitations of using ultrasound as a body composition technique appear to be the lack of standardization in the measurement technique and the results highly dependent on the operator proficiency. Therefore, the availability of new, user-friendly devices with the accompanying software, designed specifically for body composition analysis, may be desirable in the future $^{22,23}$.

Furthermore, several other less available techniques have also been suggested, such as air displacement plethysmography (ADP), dual energy x-ray absorptiometry (DXA), computed tomography (CT) and magnetic resonance imaging (MRI). These techniques can provide the most accurate data on the fat mass and offer better quantitative assessment of visceral adiposity compared to previous general and abdominal obesity anthropometric measures. ADP and DXA can provide precise measures of fat mass but can only indirectly evaluate visceral adiposity by monitoring changes in pressure within a closed chamber or by measuring the total body and trunk fat masses ${ }^{24}$. For overweight and obese patients, ADP was found to be a valid measure of fat mass, fat-free mass and percent body fat when compared with values determined by the DXA criterion ${ }^{25}$. DXA is a simple noninvasive method with short-scanning time and virtually no radiation, which can accurately measure body composition and visceral fat with high precision and help define the cardiovascular risk and the risk of diabetes ${ }^{26}$. Currently, $\mathrm{x}$-ray, CT or MRI present valuable methods and the reference standard for studying fat deposition by providing images that generate the most accurate, very specific and comprehensive data, which can be used to directly assess visceral adiposity ${ }^{24}$. A CT scan allows separate assessment of subcutaneous and visceral fat and the 
visceral fat area from a single CT slice. At the L4 level, it significantly correlates with the total visceral fat volume measured by the multi-slice CT scan ${ }^{27}$. The adipose tissue MRI technique provides a reliable, quantitative and noninvasive evaluation of central obesity, which is feasible in a clinical setting because it permits rapid and accurate assessment of the total and visceral adipose tissue. This can play a central role in the metabolic syndrome risk assessment, as well as in the visceral/total fat tissue ratio ${ }^{28}$.

\section{The Mechanisms Linking Obesity to Male Infertility}

The exact pathophysiology underlying the influence of obesity on the male reproductive potential in humans is still a matter of debate, as several possible mechanisms including hormonal, genetic or epigenetic, environmental or physical factors can play a role in addition to the negative effects of obesity per $s e^{14}$.

The reproductive hormone profiles of most obese men deviate from what is considered the norm. Visceral obesity is more likely to lead to changes in hormone levels than fat stored in other parts of the body because white adipose tissue is a major endocrine organ that secretes a number of biologically active peptides and proteins including adipose-derived hormones and adipokines. Due to obesity and the increased influx of white adipose tissue, obese men tend to present with elevated estradiol and low testosterone levels because excess adipose tissue can possibly lead to increased aromatization of testosterone. The severity of obesity determines the degree to which the levels of estradiol are increased, accompanied by decreased testosterone, SHBG and inhibin B levels. It is suggested that elevated estrogen concentrations resulting from the increased conversion of androgens into estrogens may be explained by the overactivity of the aromatase cytochrome P450 enzyme, which is expressed at high levels in white adipose tissue. The increase in estrogen and decrease in testosterone levels, in addition to lowered levels of inhibin B, deleteriously affect spermatogenesis and testicular function locally. Furthermore, high estrogen levels contribute to the negative feedback effect in the hypothalamus leading to decreased pulses of gonadotropin-releasing hormone $(\mathrm{GnRH})$ and consequently decreased release of follicle-stimulating hormone (FSH) and luteinizing hormone (LH).
Therefore, it seems that dysregulation of the hypothalamic-pituitary-gonadal (HPG) axis as a consequence of male obesity might further explain the increased risks of sperm disorders and infertility ${ }^{7,29-31}$. Another key hormone produced by white adipose tissue is leptin the production of which increases with the amount of body fat and which plays a pivotal role in regulating the energy intake and expenditure. In the hypothalamus, leptin mainly targets its receptors by counteracting the effects of neuropeptide $\mathrm{Y}$ and modulating $\mathrm{GnRH}$ function through glutamate signaling or through a recently identified hormone called kisspeptin. Under normal conditions, leptin acts at all levels of the HPG axis increasing the production of $\mathrm{GnRH}$ and gonadotropins, stimulating steroidogenesis in Leydig cells, and increasing spermatogenesis by stimulating the activity of Sertoli cells. However, most of the obese individuals become insensitive to increased leptin production and develop hormonal resistance, which enables its stimulatory effects on the hypothalamic neurons and the resultant pituitary secretion of gonadotropins. Therefore, hyperleptinemia in males with obesity as a consequence of $\mathrm{GnRH} / \mathrm{FSH} /$ LH disruption may contribute to aromatase overactivity in reducing testosterone levels and decreasing spermatogenesis resulting in hypogonadism and subfertility $^{32,33}$. Furthermore, insulin, another important mediator and modulator of the HPG axis beside leptin, has recently been reported as a contributing factor in the regulation of the male reproductive potential. As key stimulatory players, both hormones have demonstrated a direct or indirect effect on GnRH, LH and FSH centrally and on Leydig and Sertoli cell function 1ocally. However, obesity is associated with increased serum and seminal insulin and leptin concentrations, which may additionally impact the male reproductive capacity leading to decreased sperm concentration and sperm vitality, and increased sperm mitochondrial membrane potential and DNA fragmentation ${ }^{33,34}$. In contrast to leptin, currently available data suggest a largely inhibitory role of adiponectin on the hypothalamus, pituitary and male gonads, however, circulating levels of adiponectin are often decreased in obesity $^{33,35}$. Furthermore, a number of various adipokines at higher concentrations from excess white adipose tissue have been linked to male infertility. It was shown that two adipocyte-released adipokines (tumor necrosis factor- $\alpha$ and interleukin-6) significantly reduced 
human sperm progressive motility in a dose- and timedependent manner, by promoting the elevation of nitric oxide production to pathological levels ${ }^{36}$. Moreover, increased release of adipokines results in inflammation and can have a toxic effect on spermatozoa through the release of excess reactive oxygen species and reactive nitrogen species $^{37}$.

Several syndromes including Klinefelter, PraderWilli, Laurence-Moon-Bardet-Biedel, Prader-Willi and Alström due to different genetic abnormalities, display to various degrees, both obesity and infertility $^{38}$. Furthermore, aromatase polymorphism may influence the levels of estradiol in men by differentially modulating the quantitatively greater effects of obesity. This could explain why only certain obese men experience this rise in estradiol and subsequent fertility problems, whereas others experience no fertility issues $^{39}$. Moreover, factors secreted by the adipose tissue are able to alter the epigenetic regulation of genes by which the body responds to environmental pressures critical to the reproductive function ${ }^{40}$.

A growing number of reports suggest that chemical and physical agents in the environment, introduced and spread by human activity, may negatively affect male fertility. Most environmental contaminants are lipophilic and accumulate in fatty tissue around the scrotum and testes or elsewhere in the body. Epidemiological studies evaluating the impact of environmental exposures to pesticides, phthalates, polychlorinated biphenyls (PCBs), air pollution, trihalomethanes and mobile phones on semen quality suggest awareness of environmental factors which may have a detrimental effect on the semen quality ${ }^{41}$. Although PCBs were banned by most countries several decades ago, the general population continues to be exposed due to their persistence and bioaccumulation and therefore concerns regarding the altered male fertility in relation to $\mathrm{PCB}$ remain present ${ }^{42}$. Although the results of studies analyzing the impact of pesticides on male fertility are not consistent, it seems that pesticide exposure may affect spermatogenesis, leading to poor semen quality and reduced reproductive potential ${ }^{43}$. Many obese men with increased visceral fat distribution have a higher level of scrotal fat and this can in conjunction with a more sedentary lifestyle lead to increased testicular temperature. Elevation of scrotal temperature is one of the major factors that impairs spermatogenesis and steroidogenesis in testis with varicocele and is associated with reduced sperm motility, increased sperm DNA damage and increased sperm oxidative stress. Therefore, thermoregulatory failure leading to testicular heat stress can compromise sperm quality and increase the risk of infertility through the molecular mechanisms including apoptosis, DNA damage and autophagy ${ }^{44}$. On assessing the functional thermal impairment secondary to varicocele, the scrotal thermoregulatory model indicates that varicocele alters the local heat exchange processes between cutaneous layers and inner structures ${ }^{45}$. A1though no overall association may be observed between regular physical activity and semen quality, bicycling at levels of $\geq 5$ hours per week has been associated with a reduced sperm concentration and total sperm count $t^{46}$.

\section{Treatment}

Given the apparent correlation between obesity and male infertility, treatment approaches should primarily focus on the management of obesity and the obesity-related health issues. This can include lifestyle modifications, pharmacological interventions and surgical options. Moreover, treatments are available not only for infertility related to obesity, but also as a treatment for other comorbidities arising from obesity ${ }^{14}$. Lifestyle changes that lead to weight loss include diet modifications, as well as making conscious efforts to exercise more in order to achieve a normal energy balance. Natural weight loss is the cornerstone and regular exercise the first-line treatment of obesity-related infertility. Although reduction in body weight is mostly associated with a consistent increase in SHBG, testosterone, $\mathrm{LH}$ and FSH levels and a reduction in estradiol, not much is known about the impact of diet/ exercise interventions on the semen parameters in obese $\mathrm{men}^{47}$. In the first cohort study of 44 severely obese men having participated in a 14-week weight loss program, weight loss was associated with an increase in total sperm count and semen volume in addition to improvement in testosterone, SHBG and anti-müllerian hormone levels ${ }^{48}$. Pharmacological methods employed in obesity-related male subfertility include the use of several drugs, such as aromatase inhibitors, estrogen receptor modulators, gonadotropins, phosphodiesterase inhibitors, and insulin-sensitizing agents ${ }^{49}$. Among them, aromatase inhibitors represent 
a highly effective option, which was successfully used in several case series with promising results. However, aromatase inhibitors, as well as estrogen receptor modulators, are not licensed for the treatment of male hypogonadism and/or infertility and therefore these treatments should be considered experimental until the ongoing clinical trials report their outcomes ${ }^{50-52}$. In conclusion, to date, there is no evidence-based treatment that increases the likelihood of pregnancy when it comes to men with obesity-induced infertility ${ }^{49}$. Among surgical interventions that are used in the treatment of infertility in obese men, the outcome of in vitro fertilization in mildly obese individuals was more favorable in comparison to severe or morbidly obese (BMI $\left.\geq 40 \mathrm{~kg} / \mathrm{m}^{2}\right)$ patients, as evidenced by lower pregnancy rates ${ }^{53}$. Therefore, for individuals who are severely obese or who have failed to lose sufficient weight after dietary modifications and pharmacological treatment, bariatric surgery is recommended as the most reliable treatment of obesity ${ }^{54}$. Although natural weight loss is the cornerstone in the treatment of obesity-related infertility, with promising results in restoring fertility and normal hormonal profiles, bariatric surgery results in greater improvements in terms of weight loss outcomes and weight associated comorbidities when compared with other non-surgical interventions. However, the impact of bariatric surgery on male fertility, pregnancy and miscarriage rates, as well as optimal timing of pregnancy is still unclear and therefore well structured clinical trials and further research are necessary to answer these questions ${ }^{14,55,56}$.

\section{Conclusion}

In recent years, the worldwide obesity pandemic has grown to concerning proportions. The negative impact of obesity on the reproductive potential of male partner has been studied to a lesser extent. Although no consensus has been reached, numerous studies clearly show that male obesity is associated with reduced fertility in men due to hormonal, genetic, physical and environmental mechanisms which ultimately lead to abnormal semen parameters. In the management of obesity-related male infertility, natural weight loss is the cornerstone and regular exercise the firstline treatment. Although bariatric surgery results in greater improvements in terms of weight loss outcomes in comparison to non-surgical interventions, further investigations are required to clarify its influence on male fertility.

\section{References}

1. Hruby A, Hu FB. The epidemiology of obesity: a big picture. Pharmacoeconomics. 2015;33:673-89. doi: 10.1007/s40273014-0243-x.

2. Ng M, Fleming T, Robinson M, Thomson B, Graetz N, Margono $\mathrm{C}$, et al. Global, regional, and national prevalence of overweight and obesity in children and adults during 1980-2013: a systematic analysis for the Global Burden of Disease Study 2013. Lancet. 2014;384:766-81. doi: 10.1016/S0140-6736(14) 60460-8

3. Nguyen DM, El-Serag HB. The epidemiology of obesity. Gastroenterol Clin North Am. 2010;39:1-7. doi: 10.1016/j.gtc. 2009.12.014.

4. Pinborg A, Gaarslev C, Hougaard CO, Nyboe Andersen A, Andersen PK, Boivin J, et al. Influence of female bodyweight on IVF outcome: a longitudinal multicentre cohort study of 487 infertile couples. Reprod Biomed Online. 2011;23:490-9. doi: 10.1016/j.rbmo.2011.06.010.

5. Talmor A, Dunphy B. Female obesity and infertility. Best Pract Res Clin Obstet Gynaecol. 2015;29:498-506. doi: 10.1016/j. bpobgyn.2014.10.014.

6. MacDonald AA, Herbison GP, Showell M, Farquhar CM. The impact of body mass index on semen parameters and reproductive hormones in human males: a systematic review with metaanalysis. Hum Reprod Update. 2010;16:293-311. doi: 10.1093/ humupd/dmp047.

7. Aggerholm AS, Thulstrup AM, Toft G, Ramlau-Hansen CH, Bonde JP. Is overweight a risk factor for reduced semen quality and altered serum sex hormone profile? Fertil Steril. 2008; 90:619-26

8. Macdonald AA, Stewart AW, Farquhar CM. Body mass index in relation to semen quality and reproductive hormones in $\mathrm{New}$ Zealand men: a cross-sectional study in fertility clinics. Hum Reprod. 2013;28:3178-87. doi: 10.1093/humrep/det379.

9. Sermondade N, Faure C, Fezeu L, Steegers-Theunissen RP, Zorn B, Polotsky AJ, et al. BMI in relation to sperm count: an updated systematic review and collaborative meta-analysis. Hum Reprod Update. 2013;19:221-31. doi: 10.1093/humupd/ dms050.

10. Dupont C, Faure C, Sermondade N, Boubaya M, Eustache F, Clément P. Obesity leads to higher risk of sperm DNA damage in infertile patients. Asian J Androl. 2013;15:622-5. doi: 10.1038/aja.2013.65.

11. Eisenberg ML, Kim S, Chen Z, Sundaram R, Schisterman EF, Buck Louis GM. The relationship between male BMI and waist circumference on semen quality: data from the LIFE study. Hum Reprod. 2014;29:193-200. doi: 10.1093/humrep/ $\operatorname{det} 428$. 
12. Corona G, Rastrelli G, Filippi S, Vignozzi L, Mannucci E, Maggi M. Erectile dysfunction and central obesity: an Italian perspective. Asian J Androl. 2014;16:581-91. doi: 10.4103/ 1008-682X.126386.

13. McPherson NO, Lane M. Male obesity and subfertility, is it really about increased adiposity? Asian J Androl. 2015;17: 450-8. doi: 10.4103/1008-682X.148076.

14. Cabler S, Agarwal A, Flint M, Du Plessis SS. Obesity: modern man's fertility nemesis. Asian J Androl. 2010;12:480-9. doi: 10.1038/aja.2010.38.

15. Popkin BM. Recent dynamics suggest selected countries catching up to US obesity. Am J Clin Nutr. 2010;91:284-8. doi: 10.3945/ajen.2009.28473C.

16. Pasco JA, Nicholson GC, Brennan SL, Kotowicz MA. Prevalence of obesity and the relationship between the body mass index and body fat: cross-sectional, population-based data. PLoS One.2012;7:e29580.doi:10.1371/journal.pone.0029580.

17. Janssen I, Katzmarzyk PT, Ross R. Waist circumference and not body mass index explains obesity-related health risk. Am J Clin Nutr. 2004;79:379-84.

18. Huxley R, Mendis S, Zheleznyakov E, Reddy S, Chan J. Body mass index, waist circumference and waist:hip ratio as predictors of cardiovascular risk - a review of the literature. Eur J Clin Nutr. 2010;64:16-22. doi: 10.1038/ejcn.2009.68

19. Carmienke S, Freitag MH, Pischon T, Schlattmann P, Fankhaenel T, Goebel H, et al. General and abdominal obesity parameters and their combination in relation to mortality: a systematic review and meta-regression analysis. Eur J Clin Nutr. 2013;67:573-85. doi: 10.1038/ejen.2013.61.

20. Thibault R, Pichard C. The evaluation of body composition: a useful tool for clinical practice. Ann Nutr Metab. 2012;60: 6-16. doi: 10.1159/000334879.

21. Buffa R, Saragat S, Cabras S, Rinaldi AC, Marini E. Accuracy of Specific BIVA for the assessment of body composition in the United States population. PLoS One. 2013;8:e58533. doi: 10.1371/journal.pone.0058533.

22. Wagner DR. Ultrasound as a tool to assess body fat. J Obes. 2013;2013:280713. doi: 10.1155/2013/280713

23. Ulbricht L, Neves EB, Ripka WL, Romaneli EF. Comparison between body fat measurements obtained by portable ultrasound and caliper in young adults. Conf Proc IEEE Eng Med Biol Soc. 2012;2012:1952-5. doi: 10.1109/EMBC.2012.6346337.

24. Shuster A, Patlas M, Pinthus JH, Mourtzakis M. The clinical importance of visceral adiposity: a critical review of methods for visceral adipose tissue analysis. Br J Radiol. 2012;85:1-10. doi: $10.1259 / \mathrm{bjr} / 38447238$.

25. Wingfield HL, Smith-Ryan AE, Woessner MN, Melvin MN, Fultz SN, Graff RM. Body composition assessment in overweight women: validation of air displacement plethysmography. Clin Physiol Funct Imaging. 2014;34:72-6. doi: 10.1111/ cpf.12067.

26. Kaul S, Rothney MP, Peters DM, Wacker WK, Davis CE, Shapiro MD, et al. Dual-energy $\mathrm{x}$-ray absorptiometry for quantifi- cation of visceral fat. Obesity (Silver Spring). 2012;20:1313-8. doi: 10.1038/oby.2011.393.

27. Ryo M, Kishida K, Nakamura T, Yoshizumi T, Funahashi T, Shimomura I. Clinical significance of visceral adiposity assessed by computed tomography: a Japanese perspective. World J Radiol. 2014;6:409-16. doi: 10.4329/wjr.v6.i7.409.

28. Poonawalla AH, Sjoberg BP, Rehm JL, Hernando D, Hines $\mathrm{CD}$, Irarrazaval $\mathrm{P}$, et al. Adipose tissue MRI for quantitative measurement of central obesity. J Magn Reson Imaging. 2013;37:707-16. doi: 10.1002/jmri.23846

29. Ruige JB. Does low testosterone affect adaptive properties of adipose tissue in obese men? Arch Physiol Biochem. 2011; 117:18-22. doi: 10.3109/13813455.2010.525239.

30. Katib A. Mechanisms linking obesity to male infertility. Cent Eur J Urol. 2015;68:79-85. doi: 10.5173/ceju.2015.01.435.

31. Du Plessis SS, Cabler S, McAlister DA, Sabanegh E, Agarwal A. The effect of obesity on sperm disorders and male infertility. Nat Rev Urol. 2010;7:153-61. doi: 10.1038/nrurol.2010.6.

32. Landry D, Cloutier F, Martin LJ. Implications of leptin in neuroendocrine regulation of male reproduction. Reprod Biol. 2013;13:1-14. doi: 10.1016/j.repbio.2012.12.001

33. Comninos AN, Jayasena CN, Dhillo WS. The relationship between gut and adipose hormones, and reproduction. Hum Reprod Update. 2014;20:153-74. doi: 10.1093/humupd/dmt033.

34. Leisegang K, Bouic PJ, Menkveld R, Henkel RR. Obesity is associated with increased seminal insulin and leptin alongside reduced fertility parameters in a controlled male cohort. Reprod Biol Endocrinol. 2014;12:34-9. doi: 10.1186/14777827-12-34.

35. Galic S, Oakhill JS, Steinberg GR. Adipose tissue as an endocrine organ. Mol Cell Endocrinol. 2010;316:129-39. doi: 10.1016/j.mce.2009.08.018.

36. Lampiao F, du Plessis SS. TNF-alpha and IL-6 affect human sperm function by elevating nitric oxide production. Reprod Biomed Online. 2008;17:628-31. doi: 10.1016/j.mce.2009. 08.018 .

37. Fraczek M, Kurpisz M. Inflammatory mediators exert toxic effects of oxidative stress on human spermatozoa. J Androl. 2007;28:325-33.

38. Kasturi SS, Tannir J, Brannigan RE. The metabolic syndrome and male infertility. J Androl. 2008;29:251-9. doi: 10.2164/jandrol.107.003731.

39. Hammoud A, Carrell DT, Meikle AW, Xin Y, Hunt SC, Adams $\mathrm{TD}$, et al. An aromatase polymorphism modulates the relationship between weight and estradiol levels in obese men. Fertil Steril. 2010;94:1734-8. doi: 10.1016/j.fertnstert.2009.10.037

40. Crujeiras AB, Casanueva FF. Obesity and the reproductive system disorders: epigenetics as a potential bridge. Hum Reprod Update. 2015;21:249-61. doi: 10.1093/humupd/dmu060.

41. Jurewicz J, Hanke W, Radwan M, Bonde JP. Environmental factors and semen quality. Int J Occup Med Environ Health. 2009;22:305-29. doi: 10.2478/v10001-009-0036-1. 
42. Meeker JD, Hauser R. Exposure to polychlorinated biphenyls (PCBs) and male reproduction. Syst Biol Reprod Med. 2010;56:122-31. doi: 10.3109/19396360903443658.

43. Roeleveld N, Bretveld R. The impact of pesticides on male fertility. Curr Opin Obstet Gynecol. 2008;20:229-33. doi: 10.1097/GCO.0b013e3282fcc334.

44. Durairajanayagam D, Agarwal A, Ong C. Causes, effects and molecular mechanisms of testicular heat stress. Reprod Biomed Online. 2015;30:14-27. doi: 10.1016/j.rbmo.2014.09.018.

45. Mariotti A, Di Carlo L, Orlando G, Corradini ML, Di Donato L, Pompa $\mathrm{P}$, et al. Scrotal thermoregulatory model and assessment of the impairment of scrotal temperature control in varicocele. Ann Biomed Eng. 2011;39:664-73. doi: 10.1007/ s10439-010-0191-3.

46. Wise LA, Cramer DW, Hornstein MD, Ashby RK, Missmer SA. Physical activity and semen quality among men attending an infertility clinic. Fertil Steril. 2011;95:1025-30. doi: 10.1016/j.fertnstert.2010.11.006.

47. Corona G, Rastrelli G, Monami M, Saad F, Luconi M, Lucchese $\mathrm{M}$, et al. Body weight loss reverts obesity-associated hypogonadotropic hypogonadism: a systematic review and metaanalysis. Eur J Endocrinol. 2013;168:829-43. doi: 10.1530/ EJE-12-0955.

48. Håkonsen LB, Thulstrup AM, Aggerholm AS, Olsen J, Bonde JP, Andersen CY, et al. Does weight loss improve semen quality and reproductive hormones? Results from a cohort of severely obese men. Reprod Health. 2011;8:24. doi: 10.1186/17424755-8-24.
49. Hammoud AO, Meikle AW, Reis LO, Gibson M, Peterson CM, Carrell DT. Obesity and male infertility: a practical approach. Semin Reprod Med. 2012;30:486-95. doi: 10.1055/ s-0032-1328877.

50. Loves S, Ruinemans-Koerts J, de Boer H. Letrozole once a week normalizes serum testosterone in obesity-related male hypogonadism. Eur J Endocrinol. 2008;158:741-7. doi: 10.1530/EJE-07-0663.

51. Stephens SM, Polotsky AJ. Big enough for an aromatase inhibitor? How adiposity affects male fertility. Semin Reprod Med. 2013;31:251-7. doi: 10.1055/s-0033-1345272.

52. Stokes VJ, Anderson RA, George JT. How does obesity affect fertility in men - and what are the treatment options? Clin Endocrinol (Oxf). 2015;82:633-8. doi: 10.1111/cen.12591

53. Awartani KA, Nahas S, Al Hassan SH, Al Deery MA, Coskun S. Infertility treatment outcome in subgroups of obese population. Reprod Biol Endocrinol.2009;27:7:52. doi:10.1186/14777827-7-52.

54. Encinosa WE, Bernard DM, Chen CC, Steiner CA. Healthcare utilization and outcomes after bariatric surgery. Med Care. 2006;44:706-12.

55. Reis LO, Dias FG. Male fertility, obesity, and bariatric surgery. Reprod Sci. 2012;19:778-85. doi: 10.1177/1933719112 440053.

56. Colquitt JL, Pickett K, Loveman E, Frampton GK. Surgery for weight loss in adults. Cochrane Database Syst Rev. 2014 CD003641. doi: 10.1002/14651858.CD003641.pub4.

\title{
Sažetak
}

\section{UTJECAJ MUŠKE DEBLJINE NA PLODNOST}

\author{
M. Kasum, S. Anić-Jurica, E. Čehić, T. Klepac-Pulanić,J. Juras i K. Žužul
}

Svrha ove studije bila je analizirati današnje dijagnostičke metode debljine kod odraslih muškaraca, potencijalne mehanizme koji povezuju debljinu s neplodnošću i mogućnosti liječenja s ciljem poboljšanja reprodukcijskog zdravlja. Debljina je širom svijeta poprimila epidemijski karakter s procijenjenom pojavnošću u porastu od 28,8\% do 36,9\% između 1980. i 2013. godine. U pogledu dijagnoze pretilosti razvijene su brojne jednostavne tehnike uključujući indeks tjelesne mase, omjer struka i kukova, opseg struka, analiza biolektričnog otpora, ultrazvuk i mjerenje kožnih nabora. Uz to, postoji nekoliko drugih rjeđe dostupnih no preciznijih tehnika kao što su pletizmografija na temelju istiskivanja zraka, apsorciometrija s dva izvora zračenja, kompjutorizirana tomografija i magnetska rezonancija. Uz kardiovaskularne i druge bolesti pretilost muškarca može se nepovoljno odražavati na njegovu fertilnu sposobnost poremećajem razine reprodukcijskih hormona, smanjenom kvalitetom sjemena, pojačanim lučenjem hormona i masnog tkiva i adipokina, a isto tako kroz toplinske, genetske i spolne mehanizme. Pri vođenju neplodnosti muškarca povezane s pretilošću odlučujuće je prirodno smanjenje tjelesne težine, a redovite tjelovježbe predstavljaju prvu liniju liječenja. Premda su kirurški zahvati na želucu i crijevima znatno uspješniji glede ishoda smanjenja tjelesne težine u odnosu na neoperacijske metode, potrebna su daljnja istraživanja za razjašnjenje njihovog utjecaja na plodnost muškarca.

Ključne riječi: Muškarac; Debljina - dijagnoza; Debljina - komplikacije; Neplodnost, muška - terapija 